\title{
Comparison of ease of insertion, visibility of strings and continuation rate of post-partum intrauterine copper device insertion by long inserter versus with the help of Kelly's forceps
}

\author{
Swati Shukla*, Mamta Tyagi, Smriti Gupta, Lalita Yadav
}

Department of Obstetrics and Gynecology, Subharti Medical College, Meerut, Uttar Pradesh, India

Received: 24 October 2020

Accepted: 28 November 2020

*Correspondence:

Dr. Swati Shukla,

E-mail: dr.swati2557@gmail.com

Copyright: (C) the author(s), publisher and licensee Medip Academy. This is an open-access article distributed under the terms of the Creative Commons Attribution Non-Commercial License, which permits unrestricted non-commercial use, distribution, and reproduction in any medium, provided the original work is properly cited.

\begin{abstract}
Background: The objective of the study was to compare ease of insertion, visibility of strings and continuation rate of post-partum intrauterine copper devices (PPIUCD) insertion by long inserter versus with the help of Kelly's forceps.

Methods: 100 women were enrolled in our study which was conducted in department of obstetrics and gynecology, Subharti medical college and Chattrapati Shivaji Subharti hospital (CSSH), Meerut over a period of 2 years between November 2018 and August 2020. In study comparison was done on insertion technique of PPIUCD.

Results: High fundal placement was achieved with long inserter. There was no perforation and decreased infection rate among the users with no increase in incidence of side effects and expulsion. Among 50 insertion, 1 woman (2\%) had partial expulsion, 2 women (4\%) had complete expulsion and 1 woman (2\%) got PPIUCD removed on request. Providers reported $100 \%$ easier technique. $96 \%$ satisfaction among the users.

Conclusions: The dedicated long inserter PPIUCD was found to be safe, with high acceptability among the participants and providers. Study revealed the reduced risk of infection and expulsion, providers also reported increased convenience in insertion compared to standard PPIUCD insertion techniques.
\end{abstract}

Keywords: PPIUCD, Long inserter, Kelly's forceps, Ease of insertion, Number of attempts, String visibility, Expulsion rate

\section{INTRODUCTION}

Contraception methods are the means to prevent unwanted pregnancy. Among all the available contraception methods, large women are currently using intra uterine contraception device, as it is a long-term contraceptive, reversible, safe and economical, easily available, requires minimum motivation, supervision, maintenance and does not interfere with breast feeding, highly effective, doesn't affect fertility and pregnancy is possible after its removal.

The conventional IUCD inserters are not long enough to reach postpartum uterine fundus therefore providers have to use Kelly's forceps, which requires them to remove the
IUCD from the inserter sleeve, place it at the tip of the Kelly's forceps, and then insert it into the uterus. This cannot be done by "no touch technique". To address this long inserter post-partum intrauterine copper devices (PPIUCD) are introduced, which doesn't require forceps for insertion, making insertion easy, comes preloaded therefore reducing the risk of possible contamination and damage to copper T. ${ }^{1}$

It is made from flexible silastic and can accommodate the shape of post-partum uterus. Long insertion sleeve ensures fundal placement of IUCD further reducing the risk of expulsion and facilitating insertion. ${ }^{2}$ It also has a longer string than the standard IUCD, so the problem of 
non-visibility of string will not be there, also perceiving thread ensures patient copper $\mathrm{T}$ presence.

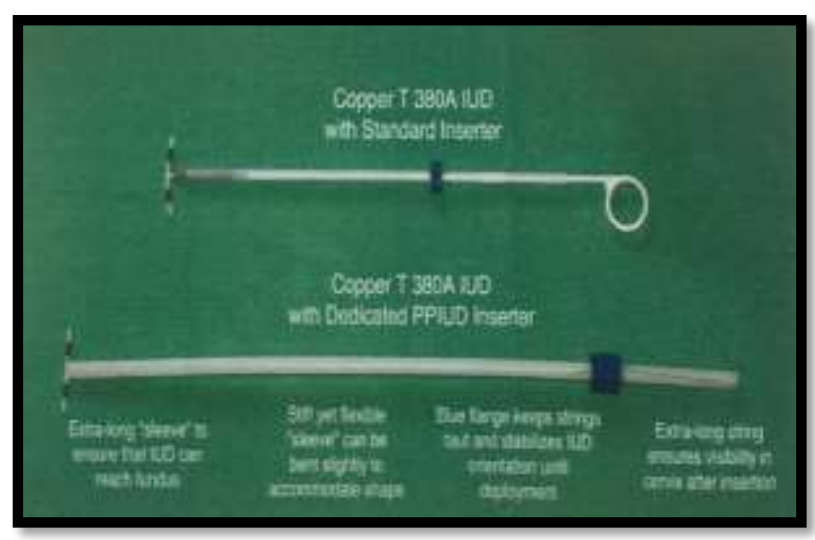

Figure 1: Postpartum intrauterine device inserter.

Aims and objectives of the study were to compare ease of insertion, visibility of strings and continuation rate of PPIUCD insertion by long inserter versus with the help of Kelly's forceps

\section{METHODS}

Prospective observational study conducted in department of obstetrics and gynecology, Subharti medical college and Chattrapati Shivaji Subharti hospital (CSSH), Meerut over a period of 2 years between November 2018 and August 2020, enrolled 100 women,50 insertion done with the help of Kelly's forceps (group A) and the other 50 with long inserter PPIUCD (group B).

The software (statistical tool) used was SPSS 23.0.

Inclusion criteria included all women of age $\geq 18$ years who deliver at Subharti medical college and have no contraindication for IUCD insertion and willing to visit hospital for regular follow up.

Exclusion criteria excluded uterine anomalies (e.g. Mullerian anomalies), unresolved PPH, chorioamnionitis or puerperal sepsis, prolonged leaking PV $>18$ hours, after 48 hours of delivery, patients in medical eligibility criteria (MEC) category 3 and $4 .^{3}$

The selected women were screened according to the inclusion and exclusion criteria and again explained about PPIUCD insertion before carrying out the procedure. Written informed consent was taken from women willing to participate in the study and for the follow up visits at 2 weeks, 6 weeks, 3 months, 6 months or earlier in case of any adverse events. At each follow up women were asked for any specific complaint, pain abdomen assessed by VAS scale, dysmenorrhea, dyspareunia, vaginal discharge/infection, bleeding per vagina, menstrual disturbances, PABC scores, visibility of strings, history of expulsion. If patient wants removal, reason for removal was noted. ${ }^{4}$

The research procedure followed was in accordance with the approved ethical standards of Chhatrapati Shivaji Subharti hospital/Subharti medical college, Meerut, Uttar Pradesh.

\section{RESULTS}

During study period, among 100 women majority belonged to age group of 20-25 years..$^{5}$ All participants had at least one living child with $44 \%$ vaginal delivery and only $12 \%$ assisted vaginal delivery. Most of the women (54\%) were not using any contraceptive previously and acknowledged doctor/health worker as major source of knowledge regarding copper $\mathrm{T}$ and others got to know about it from TV/internet, friends and relatives.

Table 1: Demographic comparison among two groups.

\begin{tabular}{|lllll|}
\hline Variables & $\begin{array}{l}\text { Group A (Kelly's } \\
\text { forceps) } \\
(\%=50\end{array}$ & $\begin{array}{l}\text { Group B (long } \\
\text { inserter) } \\
\text { n=50 }\end{array}$ \\
\hline Age (years) & & 48 & 27 & 54 \\
\hline $20-25$ & 24 & 32 & 14 & 28 \\
\hline $26-30$ & 16 & 12 & 5 & 10 \\
\hline $31-35$ & 6 & 8 & 4 & 8 \\
\hline$>35$ & 4 & & & \\
\hline Residence & & 66 & 29 & 58 \\
\hline Rural & 33 & 34 & 21 & 42 \\
\hline Urban & 17 & & & \\
\hline Type of delivery & 46 & 92 & 44 & 88 \\
\hline Normal & 4 & 8 & 6 & 12 \\
\hline $\begin{array}{l}\text { Assisted } \\
\text { vaginal }\end{array}$ & & & & \\
\hline Parity & 32 & 64 & 29 & 58 \\
\hline P1 & 12 & 24 & 16 & 32 \\
\hline P2 & & & \\
\hline
\end{tabular}

Table 2: Comparison of IUCD status among the groups at last follow-up.

\begin{tabular}{|c|c|c|c|c|c|c|}
\hline \multirow[t]{2}{*}{$\begin{array}{l}\text { IUCD } \\
\text { status }\end{array}$} & \multicolumn{2}{|c|}{$\begin{array}{l}\text { Group A } \\
\text { (Kelly's } \\
\text { forceps) } \\
(\mathbf{n}=50)\end{array}$} & \multicolumn{2}{|c|}{$\begin{array}{l}\text { Group B } \\
\text { (Long } \\
\text { inserter } \\
\text { PPIUCD) } \\
(\mathrm{n}=50)\end{array}$} & \multirow[t]{2}{*}{$\begin{array}{l}\text { Chi } \\
\text { square }\end{array}$} & \multirow[t]{2}{*}{$\mathbf{P}$} \\
\hline & $\mathbf{N}$ & $\%$ & $\mathbf{N}$ & $\%$ & & \\
\hline $\begin{array}{l}\text { Partial } \\
\text { expulsion }\end{array}$ & 1 & 2 & 1 & 2 & \multirow{3}{*}{2.58} & \multirow{3}{*}{0.19} \\
\hline $\begin{array}{l}\text { Complete } \\
\text { expulsion/ } \\
\text { removed }\end{array}$ & 4 & 8 & 2 & 4 & & \\
\hline $\begin{array}{l}\text { Removed } \\
\text { on request }\end{array}$ & 2 & 4 & 1 & 2 & & \\
\hline
\end{tabular}


In study IUCD was partially removed in one $(2.08 \%)$ woman at $6^{\text {th }}$ month and completely removed in one $(2 \%)$ woman at $6^{\text {th }}$ week and in one $(2.08 \%)$ woman at $6^{\text {th }}$ month follow up also it was removed on request in one woman $(2.04 \%)$ due to family pressure. ${ }^{6}$

Strings visibility being the important factor for both provider and the patient was taken care. String was visible in $80 \%$ at the time of insertion and at 6 weeks follow up after complete involution of uterus it was visible in $84 \%$. In $93 \%$ women string was visible after 6 months of follow up.

Table 3: Visibility of string at the time of insertion.

\begin{tabular}{|c|c|c|c|c|c|c|}
\hline \multirow[t]{2}{*}{$\begin{array}{l}\text { Strings } \\
\text { visibility }\end{array}$} & $\begin{array}{l}\text { Gr } \\
(\mathrm{Ke} \\
\text { for } \\
(\mathbf{n}=\end{array}$ & & $\begin{array}{l}\text { Gr } \\
\text { (Lo } \\
\text { ins } \\
\text { PP } \\
\text { (n= }\end{array}$ & $\begin{array}{l}\text { B } \\
\text { D) }\end{array}$ & \multirow[t]{2}{*}{$\begin{array}{l}\text { Chi } \\
\text { square }\end{array}$} & \multirow[t]{2}{*}{$\mathbf{P}$} \\
\hline & $\mathbf{N}$ & $\%$ & $\mathbf{N}$ & $\%$ & & \\
\hline Visible & 30 & 60 & 40 & 80 & \multirow{2}{*}{3.93} & \multirow{2}{*}{$0.04 *$} \\
\hline Not visible & 20 & 40 & 10 & 20 & & \\
\hline
\end{tabular}

Table 4: Visibility of string after 6 months follow up.

\begin{tabular}{|c|c|c|c|c|c|c|}
\hline \multirow[t]{2}{*}{$\begin{array}{l}\text { Strings } \\
\text { visibility }\end{array}$} & \multicolumn{2}{|c|}{$\begin{array}{l}\text { Group A } \\
\text { (Kelly's } \\
\text { forceps) } \\
(\mathbf{n}=\mathbf{5 0})\end{array}$} & \multicolumn{2}{|c|}{$\begin{array}{l}\text { Group B } \\
\text { (Long } \\
\text { inserter } \\
\text { PPIUCD) } \\
(\mathbf{n}=50)\end{array}$} & \multirow[t]{2}{*}{$\begin{array}{l}\text { Chi } \\
\text { square }\end{array}$} & \multirow[t]{2}{*}{$\mathbf{P}$} \\
\hline & $\mathbf{N}$ & $\%$ & $\mathbf{N}$ & $\%$ & & \\
\hline Visible & 40 & 86.9 & 45 & 93.7 & \multirow[b]{2}{*}{0.98} & \multirow[b]{2}{*}{0.57} \\
\hline $\begin{array}{l}\text { Not } \\
\text { visible }\end{array}$ & 6 & 13.0 & 3 & 6.25 & & \\
\hline
\end{tabular}

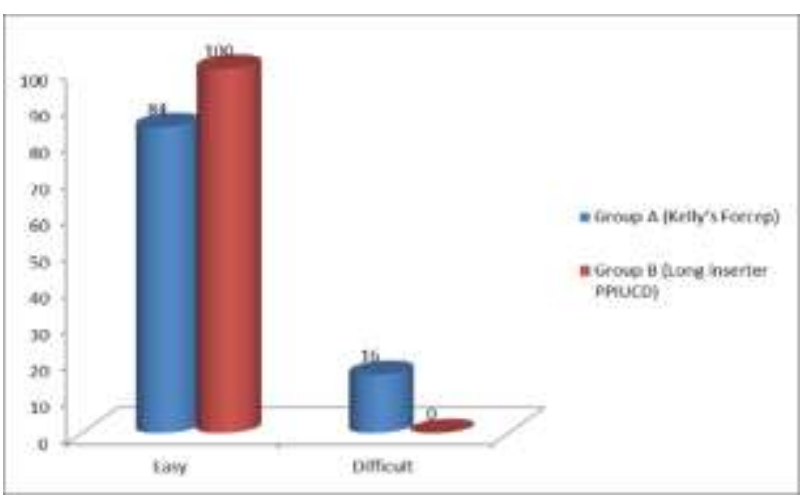

Figure 2: Comparison of ease of insertion among the groups.

Bleeding related problems is the most common side effects associated with IUCD insertion regardless of method of insertion and timing of insertion. In the first 6 weeks post-partum, changes are masked by usual irregular spotting and pain associated with uterine involution. In our study during follow up most common complaint was bleeding per vaginum, at $6^{\text {th }}$ month follow up bleeding was reported in $12 \%$ and pelvic pain reported in $4 \% .^{7}$
Table 5: Comparison of side effects among two groups.

\begin{tabular}{|c|c|c|c|c|c|}
\hline Bleeding & \multicolumn{2}{|c|}{$\begin{array}{l}\text { Group A } \\
\text { (Kelly's } \\
\text { forceps) } \\
(\%)\end{array}$} & \multicolumn{2}{|c|}{$\begin{array}{l}\text { Group B (Long } \\
\text { inserter } \\
\text { PPIUCD) (\%) }\end{array}$} & \multirow{2}{*}{$\begin{array}{l}\text { P } \\
0.12\end{array}$} \\
\hline $\begin{array}{l}2 \text { weeks } \\
(n=50)\end{array}$ & 6 & 12 & 3 & 6 & \\
\hline $\begin{array}{l}6 \text { weeks } \\
(n=50)\end{array}$ & 6 & 12 & 3 & 6 & 0.12 \\
\hline $\begin{array}{l}3 \text { months } \\
(n=50)\end{array}$ & 8 & 16 & 6 & 12 & 0.47 \\
\hline $\begin{array}{l}6 \text { months } \\
(n=48)\end{array}$ & 10 & 21 & 6 & 12 & 0.08 \\
\hline \multicolumn{6}{|l|}{$\begin{array}{l}\text { Pain } \\
\text { abdomen }\end{array}$} \\
\hline $\begin{array}{l}2 \text { weeks } \\
(n=50)\end{array}$ & 10 & 2 & 5 & 1 & 0.16 \\
\hline $\begin{array}{l}6 \text { weeks } \\
(n=50)\end{array}$ & 5 & 10 & 2 & 4 & 0.32 \\
\hline $\begin{array}{l}3 \text { months } \\
(n=50)\end{array}$ & 3 & 6 & 2 & 4 & 0.57 \\
\hline $\begin{array}{l}6 \text { months } \\
(n=48)\end{array}$ & 2 & 4 & 2 & 4 & 1 \\
\hline
\end{tabular}

Table 6: Number of attempts required to insert PPIUCD among the groups.

\begin{tabular}{|c|c|c|c|c|c|c|}
\hline \multirow[t]{2}{*}{$\begin{array}{l}\text { No. of } \\
\text { Attempts }\end{array}$} & \multicolumn{2}{|c|}{$\begin{array}{l}\text { Group A } \\
\text { (Kelly's } \\
\text { forceps) } \\
(\%)\end{array}$} & \multicolumn{2}{|c|}{$\begin{array}{l}\text { Group B } \\
\text { (Long } \\
\text { inserter } \\
\text { PPIUCD) } \\
(\%)\end{array}$} & \multirow[t]{2}{*}{$\begin{array}{l}\text { Chi } \\
\text { square }\end{array}$} & \multirow[t]{2}{*}{$\mathbf{P}$} \\
\hline & $\mathbf{N}$ & $\%$ & $\mathbf{N}$ & $\%$ & & \\
\hline 1 & 39 & 78 & 48 & 96 & \multirow{3}{*}{5.11} & \multirow{3}{*}{$0.04 *$} \\
\hline 2 & 7 & 14 & 2 & 4 & & \\
\hline$>2$ & 4 & 8 & 0 & 0 & & \\
\hline
\end{tabular}

*statistically significant

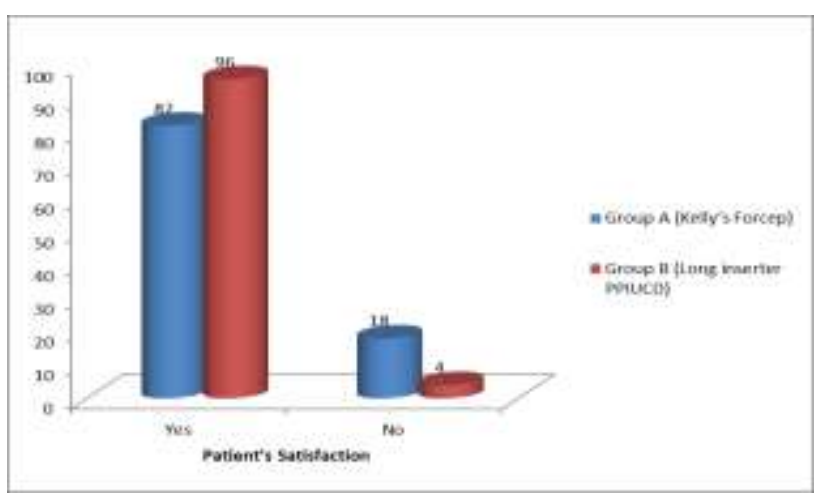

Figure 3: Patient's satisfaction.

$100 \%$ health care providers reported easy insertion of PPIUCD with long inserter, $96 \%$ insertion done in single attempt. The women satisfaction questionnaire revealed that $96 \%$ were satisfied with the counselling and the decision to get PPIUCD and would also recommend it as the method of contraception to family and friends. ${ }^{8}$ 


\section{DISCUSSION}

In the study, the long inserter PPIUCD functioned well with $96 \%$ satisfaction rate among the subjects, easy insertion, less attempts required by providers to insert. Counseling and training of the care provider (doctors, nurses and health staffs) of a hospital form integral part in the success. It was observed that people were aware of methods of contraception but were not using them due to a misconception. ${ }^{9}$

Expulsion is a major concern with PPIUCD insertion but study shows that proper placement of device with correct technique and specialized training of service provider has reduced the expulsion rates significantly. Sharad Singh et al in 80 women conducted a study between March and July 2015 among 80 participants, concluded the IUCD was completely expelled in only 6 cases $(7.5 \%)$, partially expelled in 8 cases $(10.0 \%)$, and removed in 5 cases $(6.3 \%)$ for social and clinical reasons. ${ }^{10}$ Of the 4 insertions reported by providers to be difficult, 3 resulted in complete expulsion and 1 in a partial expulsion.

Major cause of PPIUCD removal was increased bleeding related complaints, other was pain abdomen, similar findings were reported by Xess et al in 2017,conducted a study in 220 women and concluded that during follow up there was $5.5 \%$ removal at 3 months with bleeding as main reason of removal in $38.4 \%$, others complaint of pain abdomen $(23.1 \%)$ discharge $(15.3 \%)$ and family pressure $(23.1 \%){ }^{11}$

Missing strings is one of the major causes of concern and apprehension both in acceptor and provider but this issue was also resolved with long strings in dedicated PPIUCD.

\section{Limitations}

Since this study was conducted in an urban tertiary care center with a small sample size and of north Indian population, the precision of outcome estimates may be limited. Larger studies are required over varying strata of Indian population to definitely establish the comparison of ease of insertion, visibility of string, continuation rate of PPIUCD copper T 380 insertion by long inserter versus Kelly's forceps.

\section{CONCLUSION}

Overall immediate post-partum IUCD is a very safe and highly effective contraceptive method among all longacting reversible contraception. Using long inserter for PPIUCD insertion was easier and required fewer attempts, it has additional benefits of long strings. It can be inserted by using no touch technique, decreasing the risk of contamination. Study shows no increase in incidence of any complications, partial or complete expulsion compared to conventional methods.

Funding: No funding sources

Conflict of interest: None declared

Ethical approval: The study was approved by the Institutional Ethics Committee

\section{REFERENCES}

1. Blumenthal PD, Eber M, Vajpayee J. Dedicated inserter facilitates immediate postpartum IUD insertion. Glob Health Sci Pract. 2013;1(3):428-9.

2. IUCD Reference Manual for Medical Officers; Family planning Division Ministry of Health and Family Welfare Government of India. 2007;1-112.

3. World Health Organization (WHO). Medical eligibility criteria for contraception use. Geneva; WHO; 2015. Available at: https://www.who.int/ publications/i/item/9789241549158. Accessed on 2 October 2020.

4. Higham JM, O'Brien PMS, Shaw RW. Assessment of menstrual blood loss using pictorial chart. $\mathrm{Br} \mathrm{J}$ Obstet Gynaecol. 1990;97:734-39.

5. Mishra S. Tale of the tails, the missing postpartum IUCD strings. J Obste Gynecol India. 2017;67(3):202-7.

6. Roy LC, Shivakumar RN, Paprikar MM. To Study the Safety and Efficacy of Post-Partum Intra-Uterine Contraceptive Device. Int J Res Rev. 2019;6(10):252-8

7. Sudha CP, Priyanka HK, Nagaiah D. A study to evaluate safety and efficacy of immediate postpartum postplacental IUCD insertion. Int J Reproduct Contra Obste Gyneco. 2017;6:2284-8.

8. Banapurmath ST, Dotrad GB, Doreswamy N. Feasibility of post-partum insertion ofintrauterine contraceptive device-expanding the use of intrauterine contraceptive device in post-partum period-a cross sectional study in developing country, INDIA. Int J Cur Res Rev. 2014;6(14).

9. Mishra S. Evaluation of Safety, Efficacy, and Expulsion of Post Placental and Intra-Cesarean Insertion of Intrauterine Contraceptive Devices. J Obstet Gynaecol India. 2014:64(5);337-43.

10. Singh S, Das V, Agarwal A, Dewan R, Mittal P, Bhamrah $\mathrm{R}$ et al. A dedicated postpartum intrauterine device inserter: pilot experience and proof of concept. Glob Health Sci Pract. 2016;4(1):132-40.

11. Xess S, Sharma M, Rajoria L, Seema. A study to evaluate and compare the expulsion, removal and continuation of post placental insertion of $\mathrm{Cu} 375$ and $\mathrm{CuT} 380 \mathrm{~A}$ in Indian women. Int $\mathrm{J}$ Clin Obste Gynaecol. 2018;2(1):33-8.

Cite this article as: Shukla S, Tyagi M, Gupta S, Yadav L. Compare ease of insertion, visibility of strings and continuation rate of post-partum intrauterine copper device insertion by long inserter versus with the help of Kelly's forceps. Int J Reprod Contracept Obstet Gynecol 2021;10:74-7. 